\title{
ERGONYMS OF EDUCATIONAL AND CULTURAL SPHERES IN TWO OF BALTIC STATES CITIES
}

\author{
SOLVITA POŠEIKO \\ University of Latvia, Rezekne University College, Latvia \\ E-mail adress: solvita.poseiko@gmail.com
}

\section{ABSTRACT}

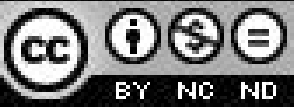

Daugavpils (Latvia) and Narva (Estonia) are cities in the Baltic States and significant cultural and economic centres of their respective countries. These cities are characterized by a minority of nationals (19.8\% of residents of Daugavpils are Latvian, $4 \%$ of residents of Narva are Estonian) and a similar linguistic situation: there is a dominance of Russian in the press, television and radio, but the state language prevails in the urban language signs.

The aim of the study is to analyse the linguistic and extralinguistic means used for the creation of ergonyms of educational and cultural spheres. The main criteria for the analysis are: language choice, grammatical structures, sources of precedent and semantic groups. The data for this study were collected in city websites.

Some conclusions:

1) Mixed proper names (the direct name and symbolical name) prevail: in Daugavpils there are more mixed names in the field of education, while in Narva there are more mixed names in the culture sphere. Onymization of nomenclature names can be observed.

2) Ergonyms are mostly created in the official language. In Narva, there is explicit use of Russian (directly as the first/second or third language and indirectly - in transliteration).

3) In symbolical names, there are more lexemes representing or characterizing wildlife, while in Narva also the potential of mythology, literature and cinema is used. Denotative precedent is more often found in the names of informal educational institutions and the cultural sphere, connotative precedent - in the names of kindergartens.

4) In general, it must be concluded that the specific things characteristic to the local environment are used more often in Narva, while respecting the unique experience of minorities.

Key words: virtual linguistic landscape, ergonyms, proper names, linguistic means, semantic groups

\section{INTRODUCTION}

Today everybody faces the diversity of information in different types of texts. It is omnipresent: on television and radio, in cafes and libraries, on the internet and in the city streets. Since the end of the $20^{\text {th }}$ century the notion of linguistic land-

This paper has been produced within the framework of the project "Atbalsts doktora studijām Latvijas Universitātē" („Support for doctoral studies at the University of Latvia”) funded by European Social Fund. 
scape has been discussed (Spolsky, Cooper, 1991; Landry, Bourhis, 1997; Gorter, 2006), by this notion meaning both the language application in different real and virtual life spheres as well as different text genres and functionalities in written messages in city environment.

The name of educational and cultural establishment is a text consisting of one word or combination of words - ergonym (Superanska, 1973; Jemeljanova, 2007; Bušs, 2013). It often consists of a proper noun and a nomenclature noun. Even other communication modes have a significant role, such as symbols, images and figures etc., nonverbal signs that complement verbal information.

Every ergonym has the denominative, informative, commercial, aesthetic, memorial and possessive designation function (Jemeljanova, 2007, p. 6), and as the most important of these are indicated the representatively identifying function, commercial and informative function (Trifinova, 2006).

An ergonym creates the first impression and associations, provides identification among others and differentiates from categorically similar establishments. As a rule foreign or local business chains, educational centers choose a neutral ergonym, which is easy to use and is not dependent on the location (Rimi, Statoil, Hesburger, Buts), however the names of local companies and educational establishments are often unique and demonstrate the sociocultural features characteristic to the local environment or on the contrary - conceals them.

\section{METHODOLOGY OF THE RESEARCH}

For the purpose of the research two cities located in the Baltic States were selected- Daugavpils (Latvia) and Narva (Estonia) - as being significant cultural and economic centers in the respective countries. The web homepages for the respective cities were studied (http://www.daugavpils.lv/ and http:// www.narva.ee/ee// - providing information about local institutions, organizations, associations etc. as well as local society unions. Names of pre-school educational establishments (and groups) were studied, names of children and youth clubs and hobby groups as well as ergonyms of national and cultural associations.

The aim of the research is to analyze the linguistic and extra-linguistic factors in the creation of educational and cultural establishment ergonyms. The main criteria for the analysis: language choice, grammatical structures, sources of precedent and semantic groups. For the purpose of data collection and sociolinguistic analysis the virtual linguistic landscape method is used and for the analysis of connotative and denotative components of names - method of structural semiotics and comparative method is used.

Structure of the article: first, the theoretical questions are discussed, supported by examples, then a general sociolinguistic characterization of the selected cities is given. Further analysis of the acquired data is given. Finally a summary of the research is presented together with the most significant conclusions. 


\section{THEORETICAL FRAMEWORK}

Three theoretical issues are significant for the research:

1. Structure and classification of ergonyms.

Institution names consist of two parts: nomenclature part, that indicates the type of organizational formation (school, hobby group, society), and differential part that provides explanation of the organizational formation (vakara vidusskola [evening school], sporta skola [sport school], kultūras biedrïba [cultural society]) (Laugale, Šulce, 2012, pp. 31-32).

In Latvian linguistics all names are divided in five groups:

- direct or real names that contain at least two components (nomenclature units and differential parts - Daugavpils Latgaliešu biedrïba [Daugavpils Latgalian Society]);

- symbolic or indirect names ([dance studio] Dzirkstelite 'Sparkle' in Daugavpils);

- mixed names (a combination of direct and symbolic name e.g. bèrnu klubs „Mezgls" [children's club “Knot"] in Daugavpils);

- abbreviations;

- complicated names with additional words or word combinations (Laugale, Šulce, 2012, pp. 32-34).

In both cities ergonyms in cultural and educational spheres are direct, symbolic or mixed names (see further).

2. Motivator of creation of names for different establishments - precedent, and its semantics.

The following can function as source groups or types of precedents: literature, movies, music, history and geography, human etc. or abstract notions. For example, the precedent for Narva dance club Flamingo is dance, the precedent of the ergonym Narva theater Voobrazilia [Imagination] is an abstract notion, and the precedent for such ergonyms as Daugavpils children garden groups Gudriši [Smart Kids], Mazulis [Baby] and Mazulǐsi [LittleOnes] - is human.

Depending on the connection between the name(-s) used in the ergonym and the denoted association of people or the establishment, the usage of the precedent may be: denotative, if the precedent used in the ergonym has a direct, real connection to the sphere of work of the respective association or establishment, or connotative, if this relation is metaphorical (Bušs, 2013, p. 53). The examples of denotative precedents: applied art hobby groups Šüšanas ābece [Sewing ABC], vocal studios Music and Singers Club that clearly enough demonstrate the purpose of hobby groups and specific of activities. But the following ergonyms are examples of connotative precedents: Daugavpils Polish national dance group Kukul̨ečka [Little cuckoo] and dance studio Paradize [Paradise], Narva vocal group Šanss [Chance] and ballet dance studio Raduga [Rainbow]. Names of kindergartens and the names of their symbolic groups almost always have connotative precedent (see further). 
The main purpose of every proper noun is to name only one object, however the actual application of nouns show that certain onyms function as designators for several objects. For example, Saulite [Sun] is a name of one kindergarten and several groups in different kindergartens in Daugavpils, Narva - name of the city, hotel, hospital, dance club and photo club. These are cases of ergonym homonyms with joint denotative semantics (inner semantics), but possibly, variable connotative semantics.

Additional external semantics or form-semantics are characteristic only to proper nouns, which are formed by natural concepts and associations, created by lexeme of the proper noun (form, graphical pattern) independent of the word's lexical basic meaning or notional contents. In the external semantics it is possible to distinguish, firstly, etymologizing semantics which are created by associations caused by inner form of the proper noun. It is of no significance it they conform to the scientific etymology. Secondly, addressing semantics, which are built by associations that the proper noun creates about the national, local, religious etc. affiliation of the respective proper noun. The probability factor is characteristic to it (Bušs, 2003, pp. 280-281). For example, the inner form of the first part of the name of the photo studio "Ezerzeme-F" [“Lakeland-F”] (Daugavpils) creates associations with a land of lakes (a region of Latvia - Latgale) ${ }^{2}$, highlighting etymologizing semantics, whereas the name of folk group Славянка [Slavic woman] (Daugavpils) or the name of Slavic culture association Svätogor [A character from Slavic mythology] suggests Slavic culture, relating it to addressing semantics.

3. Semantic groups of ergonyms.

All ergonyms can be grouped without connection between precedent and the named group of people or object. Russian linguist Oksana Jemeljanova in her analysis of ergonyms in the city environment of Ufa (Russia), divides names into five lexically semantic groups (Jemeljanova, 2007, p. 8):

- ergonyms, that are living beings or beings that are to be considered as living ones (folk group "Русичu" [A poetical designation of inhabitants of Ancient Russia] in Daugavpils, kindergarten „Pääsuke" [Swallow]' in Narva);

- ergonyms - inanimate objects and phenomenona (kindergarten Muinasjutt [Fairy tale] in Narva, applied art hobby group Palete [Palette] in Daugavpils);

- ergonyms - names of object groups (seasons, holidays, pieces of literature, art, music etc., for example, singing group Pavasaris [Spring] in Daugavpils, dance club Jun-Ost [You-th]);

- ergonyms, that are words that characterize a person or establishment (spordikool "Energia" [sport school „Energy"], studio Creative-stuudio [Creative Studio] in Narva);

Employee of the photo studio Olga Perevalova 05.01.2014. electronically informed, that the name is based on the idea of Latgale as a land of lakes that is often being photographed. The letter $F$ (abbreviation from Latvian word foto 'photo') is added, since there was already a title Ezerzeme 'Land of Lakes' registered in the system. 
- ergonyms that have unclear semantics, which are not understandable without knowing the process of creation of the name.

So basically the following criteria should be included in the research of ergonyms of establishments or institutions: organizatory formation groups of names; types of precedents, usage of denotative and connotative precedents; semantics of ergonyms and lexically semantic groups.

\section{SOCIOLINGUISTIC CHARACTERIZATION OF THE CITIES}

Daugavpils and Narva are cities of republic significance that are situated peripherally in relation to the capital city - the center. Geographically these cities have a significant role in the maintenance of national and EU borderlines, because Daugavpils is situated near Zarasi (Lithuania) and Braslava (Belarus), $120 \mathrm{~km}$ from the Russian border, whereas Narva is a direct border crossing point with Russia. During the 1920s - 1940s, Narva and Ivangoroda - a city on the other bank of the river Narva, was a single Estonian city Janilinna (Jaanilinn) which in 1945 was again divided into two separate cities.

Virtually Daugavpils is being positioned as a city where everyone should feel at home - a city that has a lot of everything: many languages, cultures and religions (http:/ / daugavpils.lv/lv/city), whereas Narva - as city of positive energy (http:// www.narva.ee/en/for_tourists/page:469). In both cases psychological well-being is emphasized, which can be acquired by living there or visiting/staying there.

The selected cities are characterized by a similar ethnodemographical situation: the native population (Latvians and Estonians) are in a minority. In Daugavpils in 2011 there were more than 93 thousands residents, of which 54\% were Russians, 20\% Latvians, 14\% Poles and 7\% Belarussians (http:/ / data.csb.gov.lv, 09.12.2013.). In Narva in 2012 there were more than 67 thousand residents, and $82 \%$ of them were Russians, 4\% Estonians, 3\% Ukrainians and 2\% Belarussians (http://web.narva. ee/files/6187.pdf, 09.12.2013.). Although this is not the latest data, it represents the main tendency - the dominance of the Slavic language and culture.

The cities have similar economical profiles, however there are differences in the educational and cultural spheres: in Daugavpils there are 11 higher education establishments (Daugavpils University and faculties of 10 other universities or institutions of higher education), in Narva there is only a branch office of Tartu University. In Daugavpils there are numerically more cultural centers (Daugavpils Kultūras pils [Daugavpils Cultural Palace], Vecās Foršstates kultūras nams [Old Forshstate Palace], Latvian culture center Vienibas nams [House of Unity]) and others, in Narva there is only one culture center Rugodiv [The ancient name of the city Narva].

Information on the homepages of both cities is available in three languages: the state language of each country, Russian and English. In the case of Narva it is the Russian language that is functionally more important, in Daugavpils - the Latvian language. The dominance of the Russian language can be seen in the mass media: the video blog of the Daugavpils municipality (http://www.tv.daugavpils.lv/) is available in both languages, however Russian is selected more frequently by the 
visitors of the web page, while in Narva the local television is broadcast only in Russian. In each city there are two local radio stations in Russian, in Narva one of these is broadcasting in two languages (Estonian and Russian). Numerically prevalent are local newspapers: in Daugavpils there are six newspapers, one of them in Latvian (with a parallel issue in Russian), and one magazine, published in Russian. In Narva there are six newspapers: five of them are published in Russian and one in Estonian. Additionally, in Daugavpils there is a magazine that is published in Polish once in a quarter and a radio programme in Polish broadcasts once in a month.

It is obvious that in both cities a relatively monolingual information space is being maintained. Since there is a tendency among youth to choose the internet as source of information, it can be assumed that young people in Daugavpils more often need national language competence in terms of data handling. However middle-aged or elderly inhabitants in both cities might not even notice any discomfort due to a lack of knowledge or incomplete competence of the state language, thus "falling ill" with linguistic (the Russian language) self-sufficiency. In terms of the preservation of language and culture of minorities, the activities of the Polish cultural center are very important.

The data acquired in the research of the external linguistic landscape (1478 language signs in Narva, 1544 language signs in Daugavpils) show that use of the state language is dominant: in Daugavpils the Latvian language is used as the first, second or third language on signboards in $88 \%$ of cases, in Narva the Estonian language - in $63 \%$ of cases. While in Narva the application of Russian language can be seen in $26 \%$ of cases, in Daugavpils it is observed more seldom - in only $5 \%$ of cases. Since the second most frequently used language is English this has been observed in $22 \%$ of language signs acquired here, it can be assumed that the public information in these cities is presented in the state language according to the language law applicable in each country. In Narva often the prevalence of the Russian speaking population is taken into consideration and a literal translation or additional information in Russian is offered. In 169 language signs it is the only language used on signboards. Meanwhile English could be referred to as communication code with a limited functionality and emotional neutrality.

When considering the names of establishments and institutions in the context of language policy, it is important to point out that according to the language laws in both countries, the state language and Latin alphabet must be used, if the institution or the main part of it belongs to the state and is registered in the respective country. In the private sector, neologisms that confirm to sound and form system of each state language are allowed, but texts which are offensively or hatefully provocative are prohibited (http://likumi.lv/doc.php?id=10130, http://www. hm.ee/index.php?popup=download\&id=6912).

\section{ERGONYMS OF PRE-SCHOOL EDUCATIONAL INSTITUTIONS}

Ergonyms of secondary or higher education institutions usually do not include symbolic names (Laugale, 2009), but they are often used in ergonyms of pre-school educational institutions and educational interest centers. 
The amount of pre-school educational institutions in both cities is quite similar: in Narva - 23, in Daugavpils - 29. The essential difference is - in Daugavpils none of the educational establishments have a symbolic name: it is a serial number that differs one institution from another, for example, Daugavpils 3. pirmsskolas izglitibas iestāde [Daugavpils $3^{\text {rd }}$ Pre-school educational institution], while in Narva one of the components of the full name of kindergartens is the symbolic one, for example, lasteaed nr. 31 „Sipsik" [children garden No. 31. „Toddler”]. It means that in Daugavpils ergonyms of pre-school educational institutions are direct names, which consist of constant part - city name (astionym) and nomenclature unit - and the variable part - differential number, respectively - ordinal number. Meanwhile in Narva all kindergarten ergonyms are mixed names.

However, it does not mean that pre-school educational establishments in Daugavpils do not have historically formed symbolic names: on the homepages of kindergartens there were 22 indirect names found. For example, Daugavpils 13. pirmsskolas izglitïibas iestāde [Daugavpils $13^{\text {th }}$ pre-school educational institution] got its unofficial title Saules zakis [Sun Bunny] due to the fact that the yellow color is dominant in the interior of the kindergarten (http:/ / www.daugavpils13pii.lv/index.php?tab=1, 29.12.2013.). In this case the name is a metaphor, with the precedent being the kindergarten garden as a building, its visual design associations with light reflections. But the director of Daugavpils 23. pirmsskolas izglitïbas iestädes [Daugavpils 23 ${ }^{\text {rd }}$ pre-school educational institution] chose the symbolic name Rozite [Little Rose] because she really likes flowers (http://www.mazarozite.lv/par-mums,_29.12.2013.); they (in general - botanic) function as a source of precedent.

It is difficult to say if it is coincidence or intentional regularity that special pre-school educational establishments (4) in Daugavpils do not have additional names. From the semiotic point of view there is also the following difference: while the homepage of the common educational establishment features colorful logos, which directly represent the symbolic name (rainbow for the children garden Varaviksne [Rainbow]), special pre-school establishments do not have their own homepages at all, or they visually represent the health problem the institution is focused on - in the homepage of Daugarpils 9. speciāläs pirmsskolas izglïtibas iestādes [Daugavpils $9^{\text {th }}$ special pre-school educational institution] there is an emoticon with huge glasses - children with eyesight difficulties attend this kindergarten (http:/ 9specpii.ucoz.lv/, 02.01.2014.). But in Narva there are no special pre-school educational institutions; children with special needs do not go to separate kindergartens, there are separate groups instead that are not marked in special way linguistically or semantically.

The names of kindergartens in both cities are in the state language: in Narva transliteration is used in one case, respectively Russian word is written with Latin characters, observing the phonetic system of the Estonian language - Marjake [моряк - sailor]. On the homepages of Daugavpils kindergartens it is not possible to switch between languages, it is though possible in Narva, however the first part of the full name is translated into Russian, respectively the constant word combination - bèrnudàrzs [kindergarten] or pirmsskolas izglitìibas iestäde [pre-school educational institution] - and the number. However group names are provided 
in two languages, for example, rühm "Lapseke" - групnа "Малышок" [group "Little one"] (http:/ / lasteaiad.narvakultuur.ee/ kirsike, 02.01.2014.).

When studying creation principles of the symbolic names, it can be established that diminutives or words with a lexical meaning that express diminutive form are dominant: in Narva there were 9 diminutive forms found (Ojake [Brooklet]; Tuluke [Little Flame]; Kuldkalake [Little gold fish]; Tareke [Maisonette]), while in Daugavpils total of 20 (Bèrziñš [Little birch]; Zỉ ļuks [Little Timouse]; Rūkīitis [Dwarfy]; Pasacina [Fairytale (in diminutive form)]). These are mainly related to a positive connotation - emotionally subjective evaluation (endearment), also something being decreased in size or young from the point of view of age, as well as the child's metaphorical understanding of adults. This principle of creation is also found in symbolic names of groups of pre-school educational institutions (an exception being Daugavpils 32. pirmsskolas izglìtības iestāde [Daugavpils $32^{\text {nd }}$ pre-school educational institution], where only numeration is used - http:// www.32pii.daugavpils.lv, 03.01.2014.). For example, there are five groups in kindergarten Ābelìte [Little Apple Tree]; Gudrǐši [Smart kids]; Putninzi [Birdies]; ( $X N$ [Little Hedgehog]; Kukulǐši [Little Loafs]; Eglìte [Spurce Tree (in diminutive form)] (http:/ / www.11pii.daugavpils.lv/ par-mums, 02.01.2014.), in Narva kindergarten Ojake there are 4 groups: Pardipojad [Baby Duck]; Jänesepojad [Baby Hare]; Rebespojad [Baby Fox] and Tiigripojad [Baby Tiger] (http:/ /lasteaiad.narvakultuur.ee/ ojake, 02.12.2014). So it is obvious that all ergonyms refer to the diminutive form.

The most productive source of precedent in the creation of symbolic names of preschool educational institutions in both cities is wildlife (biology), more precisely - trees (8), insects (4), birds (4), literature, especially dominant in Narva (8), and natural phenomena (astronomy): sun (3) and rainbow (2).

In Narva characters from fairytales and literature are used, often also characters from cartoons, functioning as symbols, even as cultural themes of a certain period, for example, Potsataja [Tjeburasjka] (popular character in states of former Soviet Union); Kakuke [Little pie]; Tčipollino [Onion-boy]; Väikevend [Little Brother (from Karlsson-on-the-roof)]; Sipsik and Põngerjas [Toddler, midget]. In Daugavpils this type of semantic load is featured in the symbolic name Spriditis [Tom Thumb].

The common features in the creation of symbolic names of children gardens are living beings or creatures, or beings that are perceptible as living as motivators, as well as onymization of common nouns and their functioning as proper nouns. Differences can be seen in naming kindergarten groups: among Daugavpils' kindergarten groups there are ergonyms whose source of precedent is Latvian folklore and mythology (Jumitis; Laimina; Austrina; Auseklitis), directly or indirectly referring their connotative semantics to the specific denotation (group). However, in Narva ergonyms of separate pre-school education institutions have one precedent, for example, in kindergarten Pingviin [Penguin] all 11 groups - flowers (Moonid [Poppies]; Kelluke [Bell-flower]; Päevalill [Sunflower]; Незабудки [Forget-me-nots] - http:/ /lasteaiad.narvakultuur.ee/pingviin, 21.12.2013.), in kindergarten Punamütsike [Little Red Riding Hood] 9 groups - the precedent is Estonian Literature (Naksitrallid [Characters form literature piece Naksitrallid]; Timbu-Limbu [Estonian literature character - a girl with yellow hair]; Klaabu [Estonian literature charac- 
ter, egg-shaped creature with arms and legs]- http:/ /lasteaiad.narvakultuur.ee/ punamutsike, 21.12.2013.). In these examples the groups are conceptually united.

The following are considered to be popular group names: Bitite(s) [Little Bee(s)] (7); Saulìte [Sun (in diminutive form)] (7); Māritte(s) [Ladybird(s)] (5); Zaķišsi [Bunnies] (also Zaksis [Hare]) (5); Varaviksne [Rainbow] (4) in Daugavpils, Jänkuke (also Jänkud, Jänespojad) [Hare (Hares, Baby hare)] (5); Mesilane/ Mesilased [Bee(s)] (5); Sipelgas/Sipelgad [Ant(s)] (4); Päikene [Sun] (4) in Narva.

\section{ERGONYMS OF INTEREST EDUCATIONAL INSTITUTION}

Interest education in Daugavpils is offered by the children and youth center Jauniba [Youth], that in its structure combine 8 additional children clubs (http:/ / www.jauniba.lv/, 27.12.2013.). All of these have mixed names that contain one component that is a symbolic name. Three of the ergonyms have another onym

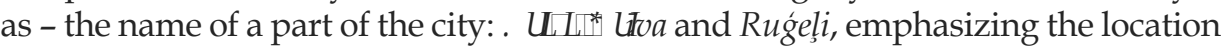
of the facility and the main area of activity. It is difficult to unequivocally evaluate the ergonym $\square \bar{e} l s i r d i b a$ [Compassion] (facility for children with special needs), that from one point of view expresses the unselfish desire to help but also indicates that the participant children are not perceived as being of equal worth compared to others, that they require special attention and the activity of the club should be perceived as a favor for children with special needs.

The center Jauniba [Youth] provides 54 different hobby groups, and 35 of them have symbolic names. Two tendencies can be observed in the creation of these names - composite names (20 word combinations consisting of two words) and the precisely defined sphere of activity - the source of precedent is the respective sphere of activity: Diedzingš [Thread]; Buroju kamols [Magic Clew]; Stils [Style] (applied art), vokälā studija [vocal studio] „Re-Mi"; akordeonistu ansamblis "Akords" [accordionist ansamble "Accordion"] (music), Müsdienu ritmi [Modern rhythms] (dance), Datoru pasaule [Computer World] (computer application), Dabas draugi [Frieds of Nature] (environment). Ergonyms often clearly show the activity type of the hobby group - Tehniskā modelēšana [Technical Modelling]; Ziedu veidošana [Flower formation]; Dekoratīvie darbi svētku noformēšanā [Ornamental works for decoration of holiday events] where a specific process functions as a proper noun combination. In two cases - Radǐšana [Creation] and Veidošana [Formation] - the source of precedent cannot be clearly identified without additional information. If in the first case the symbolic name is complemented by the existence of a differential word and nomenclature word (Jaunatnes teätris [Youth theater]), then in the second case - this type of concretizing information is lacking. Connotative precedents can be seen only in some examples: sporta dejas "Saulcerite" [sport dance club "Saulcerite"] and sport dance club "Vita" (a person).

In Narva there is a Narva Laste Loomemaaja [Narva children's creative activity house], where there are 30 different hobby groups available: 16 direct names (Floristika [Floristic]; Maleklubi [chess club]) and 14 mixed names (http://www.nll. ee/, 27.12.2013.). Precedents of denotative symbolic names are prevalent (fotostuudio "Positiiv" [photo studio „Positive”]; aeroobika stuudio „Liigutus" [aerobics 
studio „Movement"]; vokaalstuudio "Šansoon" [vocal studio "Chanson" (romantic French ballad)]; Inglise keel [the English language]), connotative precedents are more seldom (ballitantsud "Raduga" [ball dances "Rainbow"]; mängu- ja animafilmide stuudio "Rovesnik" [game and animation studio "Contemporary"]).

Analysis of language use shows that in Daugavpils names of all hobby groups are in Latvian, but in Narva separate symbolic names are being transliterated and, by switching the language in the homepage, are not being translated into Estonian. There are altogether seven such ergonyms, for example, teater "16. komnata" [theater "16 $16^{\text {th }}$ room"]; WWWXU $\square$ H WX IQD [dance club „Pearl"]; kool „Malõšok" [school „Baby"]. The English language in Narva is used in two cases - Creative-stuudio [Creative Studio] and "Aksi-Art" studio ["Aksi Art" studio].

In both cities from the lexically semantic perspective ergonyms are characterized as representatives of object groups (dziedāšanas pulciņš „Pavasaris” [singing hobby group "Spring"] - season), and more rarely as representatives of inanimate objects and phenomena (abstract notions, for example, teatrikool "Voobrazilia" [theatre school "Imagination"]).

A common feature in ergonyms of interest educational hobby groups is the prevalence of the application of denotative precedents, difference - use of the Russian language in Narva.

\section{ERGONYMS OF NATIONAL AND CULTURAL ASSOCIATIONS}

Looking at the cultural sphere, it can be seen that national and cultural associations mentioned in the homepages of both cities are unions and organizations devoted to the preservation of ethnical culture (in Daugavpils - 21, in Narva 17). They are focused on preserving both national culture (Latvian, Latgallian, Estonian), and the culture of minorities (in Daugavpils - Ukrainian, Polish, Tatar, Lithuanian, Roma in Narva - Belorussian, Uzbek, Swiss, Chuvash). Due to the number of members in certain associations and as a result of great activity, several unions have been formed; for example, three Russian culture unions in Daugavpils, two such in Narva, and two Polish culture unions in both cities. In Narva there is also a Slavic culture union.

Studies of the structural formation of names show that in Narva there are 11 direct names, in Daugavpils - there are 9 (Narva Poola Selts [Narva Polish Society]; Dvinskas kultūras biedriba [Dvinska Culture Society] in Daugavpils), and there are 12 mixed names in Daugavpils, and 8 such names in Narva (Čigānu kultūras attistibas biedriba [Gipsy culture development society "ME-Roma”]; Narva Valgevene Selts "Sjabrö" [Narva Belorussian society „Neighbors”]).

There is a tendency to present ergonyms in the language of the ethnic culture (society "Erfolg" (German) ["Success, luck"]; Poola klubi "Polonez" [Polish club „Polonaise"]) or often in transliterated form (Daugavpils Ukrainu kultūrizglitïibas biedriba "Mrija" [Daugavpils Ukrainian culture-education society “Dream"]; Vene Kogukond "Rusitš" [Russian society "Rusich”]). On the Narva homepage, ergonyms are also given in Russian, while on the Daugavpils homepage there is a 
tendency to list the associations with capital letters which do not confirm to the spelling norms of the Latvian language.

Symbolical names in the terms of semantics are lexically characterized by application of abstract notions: Harmonie [Harmony] and 1 DGHGD[Hope] in Narva, Uzdim [Upheaval, rise] in Daugavpils, which are related to spiritual processes and the psychological state of humans, indirectly indicating favorable conditions or result, focusing on positive feelings and even a movement (in the last example). In Daugavpils, category of space is topical: Vatan [Motherland] and Promien [Range], thus indicating belonging to a certain space, also symbolically. But in Narva mythology and literature are topical, for example the Slavic culture society - Svätogor [a character from Slavic mythology], but the Chuvash society's name Narspi is a [Chuvash poem that was written by Ivanov Constantine].

To summarise, it can be concluded that in Daugavpils there are potentially more symbolic names, minority languages are used for the creation of these names and application of connotative precedent is rather frequent.

\section{SUMMARY AND MOST SIGNIFICANT CONCLUSIONS}

The unifying and identifying functions are those that are important in terms of ergonyms in educational and cultural spheres, therefore the choice of language and source of precedent are of important extralinguistic significance.

In the cities generally, mixed ergonyms are more common, where one of the components is a symbolic name (nomen or a group of nomens). This type of name in the educational sphere is more frequent in Daugavpils, but in the cultural sphere they are more common in Narva. In both cities, self-dependency of nomenclature words can be observed, as well as their functionality as proper nouns.

Language choice in the case of ergonyms in the spheres of culture and education has been defined by historical conditions (the unification of two cities in case of Narva), geographical factors and modern sociolinguistic situation: the prevalence of the Russian language in spoken communication and mass media, the prestige of the English language and its role in inter-cultural relations. Although names most often can be read in the state language, the Russian language in the names of institutions (especially in Narva) is used both directly as a parallel language in the virtual environment, and even indirectly - in cases of transliteration.

The study of precedent sources and semantic groups shows that in the symbolic names under consideration, lexemes which represent or characterize wildlife (humans, animals, plants) are more frequent, in Narva the potential of literature, mythology and movies is frequent. A denotative precedent is more often applied for names in the spheres of culture and interest education, while connotative precedent are used for the names of kindergartens.

In, general it can be concluded that in Narva the characteristics and specification typical to the local environment are topical (for example, diverse application of the city name), also paying respect to the peculiar experience of minorities (including local majorities). 


\section{REFERENCES}

\section{Literature}

Bušs, O. (2003), Īpašvārdu semantika (interpretācijas mēǵinājums) [Semantics of proper names (interpretations attempt)]. In: O. Bušs, Personvārdi, vietvārdi un citi vārdi: izpētes pakāpieni [Person names, place names and other names: research steps] (pp. 275-282). Rīga: LU Latviešu valodas institūts.

Bušs, O. (2013). Īpašvārdi ekonomikā Gß̧DVI] Sētes iespējas pasaulē un Latvijā [Proper names in economy: some possibilities for the research both in all world and in Latvia]. Vārds un tā pétīšanas aspekti 17 (1), 50-55, Liepāja: Liepājas Universitāte.

Centrālā statistikas pārvalde datu bāzes [Central Statistical Bureau database]. Retrieved May 12, 2014, from http:// data.csb.gov.lv.

Gorter, D. (ed.) (2006). Linguistic Landscape: A New Approach to Multilingualism. Clevedon: Multilingual Matters.

Jemeljanova, А. М. [Емельянова, А. М.] (2007). Эргонимы В лингвистическом ландиадте полиэтнического города [Ergonyms in linguistic landscape of multiethnic city]. Ufa: ВАК РФ.

Landry, R., \& Bourhis, R. Y. (1997). Linguistic Landscape and Ethnolinguistic Vitality. Empirical Study. Journal of Language and Social Psychology, 16 (1), 23-49.

Language Act, Passed 21 February 1995. (1995). Retrieved from http://www.hm.ee/index,php?popup= download\&id $=6912$.

Laugale, V., \& Šulce Dz. (2012). Galvenie problēmjautājumi nosaukumu veidošanā un rakstībā [Main challenges in creation names and spellings]. In: V. Laugale, \& Dz. Šulce, Lielo burtu lietojums latviešu valodā: ieskats vēsturiskajā izpētē, problèmas un risinājumi [Use of capital letters in Latvian language: introduction in historical research, problems and solutions] (pp. 29-36). Rīga: LVA.

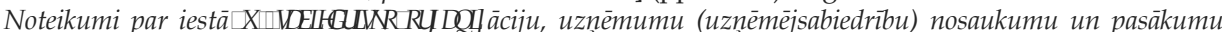
nosaukuтu veidošanu un lietošanu [Regulations issued by Cabinet (of Ministers) of the creation and use of institutions, organizations, business (company) names and measure names]. (2012). Retrieved from_http://likumi.lv/doc.php?id=10130.

Spolsky, B., \& Cooper, R. L. (1991). The Languages of Jerusalem. Oxford: Clarendon Press.

Программа Развития Города Нарва 2008-2017 [The Programme of the Development of the City of Narva 2008-2017]. (2007). Retrieved from http:// web.narva.ee/files/6187.pdf.

Суперанская, А. В. [Superanskaya, A. V.] (1973). Общая теория имени собственного [General theory of the proper name]. Moskva: Наука.

Трифонова, Е. А. [Trifonova, Е. А.] (2006) Названия деловых объектов: семантика, прагматика, поэтика: На материале русских и англииских эргонимов [Names of business object: semantics, pragmatics, poetics: Materials of Russians and English ergonyms]. Volgograd: Prorector.

\section{Kindergardens in Daugavpils:}

Daugavpils pilsētas 13. pirmskolas izglitïbas iestäde [Daugavpils 13 $3^{\text {nd }}$ pre-school educational institution]. Retrieved May 12, 2014, from http:/ / www.daugavpils13pii.lv.

Daugavpils pilsêtas 23. pirmskolas izglitỉibas iestäde [Daugavpils 23nd pre-school educational institution]. Retrieved May 12, 2014, from http:// www.mazarozite.lv, 12.05.2014.

Daugavpils pilsêtas 9. speciälā pirmskolas izglitỉibas iestäde [Daugavpils $9^{\text {nd }}$ special pre-school educational institution]. Retrieved May 12, 2014, from http:/ 9specpii.ucoz.lv/,12.05.2014.

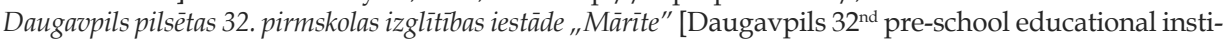
tution “ Ladybird"]. Retrieved May 12, 2014, from http://www.32pii.daugavpils.lv, 12.05.2014.

Daugavpils pilsētas 11. pirmskolas izglitíibas iestäde [Daugavpils $11^{\text {nd }}$ pre-school educational institution]. Retrieved May 12, 2014, from http:/ / www.11pii.daugavpils.lv, 12.05.2014.,,Bērziňs"”

Daugavpils pilsētas 3. pirmskolas izglïtïbas iestäde [„Little birch" Daugavpils $3^{\text {nd }}$ pre-school educational institution]. Retrieved May 12, 2014, from http:/ / www.daugavpils3pii.lv, 12.05.2014.

Daugavpils pilsētas 24. pirmskolas izglītibas iestāde "Rükīitis" [Daugavpils $24^{\text {nd }}$ pre-school educational institution "Dwarfy"]. Retrieved May 12, 2014, from http:/ / www.rukitis24pii.lv/, 12.05.2014.

Daugarpils pilsētas "Pasacina”" 10. pirmskolas izglïtibas iestāde [Daugavpils "Fairytale" $10^{\text {nd }}$ pre-school educational institution]. Retrieved May 12, 2014, from http:/ / www.daugavpils10pii.lv, 12.05.2014.

Daugavpils pilsētas 30. pirmskolas izglitiibas iestāde "Sprīditis" [Daugavpils 30 nd pre-school educational institution "Tom Thumb"]. Retrieved May 12, 2014, from http://www.daugavpils30pii.lv, 12.05.2014. 
"ZZị̧uks" Daugavpils pilsētas 26. pirmskolas izglìtïbas iestāde [„Little Timouse” Daugavpils 26 nd pre-school educational institution]. Retrieved May 12, 2014, from http://www.ziluks.lv/, 12.05.2014.

\section{Kindergardens in Narva:}

Koolieelne Lasteasutus KIRSIKE [Pre-school educational institution LITTLE CHERRY]. Retrieved May 12, 2014, from http:/ / lasteaiad.narvakultuur.ee/ kirsike, 12.05.2014.

Koolieelne Lasteasutus PINGVIIN [Pre-school educational institution PENGUIN]. Retrieved May 12, 2014, from http:/ /lasteaiad.narvakultuur.ee/pingviin, 12.05.2014.

Koolieelne Lasteasutus PUNAMÜTSIKE [Pre-school educational institution LITTLE RED RIDING HOOD]. Retrieved May 12, 2014, from http:/ / lasteaiad.narvakultuur.ee/ punamutsike, 12.05.2014.

Koolieelne Lasteasutus SPISIK [Pre-school educational institution TODDLER]. Retrieved May 12, 2014, from http:/ / lasteaiad.narvakultuur.ee/sipsik, 12.05.2014.

Narva Lasteaed MARJAKE [Narva kindergarden SAILOR]. Retrieved May 12, 2014, from http:/ / www. marjake.ee/ee/lasteaiast, 12.05.2014.

Koolieelne Lasteasutus OJAKE [Pre-school educational institution BROOKLET]. Retrieved May 12, 2014, from http:/ / lasteaiad.narvakultuur.ee/ojake, 12.05.2014.

Koolieelne Lasteasutus TULUKE [Pre-school educational institution LITTLE FLAME]. Retrieved May 12, 2014, from http:/ / lasteaiad.narvakultuur.ee/tuluke, 12.05.2014.

Koolieelne Lasteasutus KULDKALAKE [Pre-school educational institution LITTLE GOLD FISH]. Retrieved May 12, 2014, from http:/ / lasteaiad.narvakultuur.ee/kuldkalake,12.05.2014.

Koolieelne Lasteasutus TAREKE [Pre-school educational institution MAISONETTE]. Retrieved May 12, 2014, from http:/ / lasteaiad.narvakultuur.ee/tareke,12.05.2014.

\section{Interest Educational Institutions:}

Daugavpils: http://www.jauniba.lv/ (Retrieved November 24, 2013).

Narva: http:/ / www.nll.ee/ (Retrieved November 24, 2013).

National and Cultural Associations:

Daugavpils: http://daugavpils.lv/lv/97 (Retrieved November 24, 2013)

Narva:http:// www.narva.ee/ru/gorosaninu/narva_cegodna/obsectvo/page:529(RetrievedNovember 24, 2013). 